\title{
Faecal elastase 1: a novel, highly sensitive, and specific tubeless pancreatic function test
}

\author{
Chr Löser, A Möllgaard, U R Fölsch
}

\begin{abstract}
Background-Indirect pancreatic function tests available today are unreliable for clinical practice in early chronic pancreatitis due to their low sensitivity in mild and moderate exocrine pancreatic insufficiency.

Aim-To evaluate the sensitivity, specificity, and practicability of faecal elastase 1 determination in patients with mild, moderate, and severe exocrine pancreatic insufficiency categorised according to the secretin-caerulein test as 'gold standard'. Patients and methods-Faecal and duodenal elastase 1 concentration (commercial enzyme linked immunosorbent assay (ELISA)), faecal chymotrypsin activity, faecal fat analysis, and the secretincaerulein test were performed on 44 patients with mild $(n=8)$, moderate $(n=14)$, and severe $(n=22)$ exocrine pancreatic insufficiency and 35 patients with gastrointestinal diseases of nonpancreatic origin. Fifty healthy volunteers were studied as normal controls. Morphological examinations were carried out to definitely confirm or exclude chronic pancreatitis.
\end{abstract}

Results-With a cut off of $200 \mu \mathrm{g}$ elastase $1 / g$ stool the sensitivity was $63 \%$ for mild, $100 \%$ for moderate, $100 \%$ for severe, and $93 \%$ for all patients with exocrine pancreatic insufficiency, and specificity was $\mathbf{9 3} \%$. Values for chymotrypsin were $64 \%$ (sensitivity) and $89 \%$ (specificity). Significant $(p<0.001)$ correlations were found for faecal and duodenal elastase with duodenal lipase, amylase, trypsin, volume, and bicarbonate output. Individual day to day variations of faecal elastase 1 concentrations were very low (mean $\mathrm{CV}=15 \%$ ) and sample storage at room temperature is possible for at least one week.

Conclusions-Faecal elastase 1 determination proved to be a highly sensitive and specific tubeless pancreatic function test.

(Gut 1996; 39: 580-586)

Keywords: chronic pancreatitis, lipase, pancreatic insufficiency, pancreatic function test, secretincaerulein test.

The diagnosis of chronic pancreatitis is hampered by the absence of easily available histological confirmation and is therefore based on morphological and functional variables. ${ }^{1-3}$ Direct pancreatic function tests such as the secretin-cholecystokinin or secretin-caerulein test have the highest sensitivity and specificity for the detection of exocrine pancreatic insufficiency and remain the 'gold standard' for testing pancreatic function. ${ }^{3-6}$ Direct pancreatic function tests, however, have various practical disadvantages: they are time consuming, invasive, expensive, uncomfortable, not standardised, and require fluoroscopic tube placement. Therefore the secretin-caerulein test is unsuitable for routine application and is confined to a few academic centres.

Several simple indirect pancreatic function tests for clinical practice, such as the fluorescein dilaurate test, NBT-PABA or bentiromide test, faecal chymotrypsin determination, or different breath tests, have been established. ${ }^{1357}$ However, these proved to have limited sensitivity in mild and moderate exocrine pancreatic insufficiency and are interfered with by some drugs, diarrhoea, $\mathrm{pH}$, and gastrointestinal operations, which lower their specificity. In general these indirect pancreatic function tests are unreliable for clinical practice in early chronic pancreatitis $^{1-3} 589$ and the search continues for a sensitive as well as a practical test to definitely prove or exclude exocrine pancreatic insufficiency.

Recently pancreatic elastase 1 was isolated and further characterised as a human and pancreas specific enzyme that is not degraded during intestinal transport and which is five to sixfold enriched in faeces compared with duodenal juice. ${ }^{10-12}$ Furthermore, a highly sensitive enzyme linked immunosorbent assay (ELISA) for human faecal and duodenal elastase 1 determination using two specific monoclonal antibodies is commercially available. ${ }^{1011}$ Early clinical studies gave promising results in patients with exocrine pancreatic insufficiency for determination of faecal elastase 1 concentration in comparison with the fluorescein dilaurate test ${ }^{1314}$ and in a few patients compared with the secretin-caerulein test as well. ${ }^{15} 16$

The aim of the present study was to evaluate (a) the sensitivity and specificity of faecal elastase 1 determination in a sufficient number of patients with exocrine pancreatic insufficiency in comparison with the 'gold standard' of pancreatic function testing, the secretin-caerulein test; $(b)$ to characterise the sensitivity of the test according to a subclassification of patients with mild, moderate, and severe exocrine pancreatic insufficiency; (c) to compare these results with the 
determination of faecal chymotrypsin activity; (d) to perform various correlation studies to further characterise clinically important variables; and $(e)$ to determine the practicability and clinical handling of faecal elastase 1 analysis with regard to individual day to day variations, problems of sample storage, and temperature dependency of sample analysis.

\section{Methods}

CLASSIFICATION OF PATIENTS

Seventy nine consecutive patients with clinically suspected chronic pancreatitis were referred to our clinic for the secretin-caerulein test. Morphological criteria according to the Cambridge classification ${ }^{17} 18$ were assessed by ultrasonography, abdominal computed tomography, or endoscopic retrograde pancreatography (ERP) to confirm or exclude chronic pancreatitis.

Thirty five patients had a normal secretincaerulein test and no morphological signs of chronic pancreatitis. The following nonpancreatic gastrointestinal diseases were confirmed by further diagnostic investigations: erosive gastroduodenitis or gastric or duodenal ulcer $(n=15)$, coeliac disease $(n=3)$, gastrooesophageal reflux $(n=2)$, Crohn's disease $(n=2)$, cholecystitis $(n=1)$, gastric cancer $(n=1)$, and functional diarrhoea $(n=11)$.

Forty four patients had a pathological secretin-caerulein test together with morphological criteria as defined in the Cambridge classification..$^{17}$ According to the results of the secretin-caerulein test these patients with chronic pancreatitis were subclassified ${ }^{319}$ into mild ( $I ; n=8$ ) (pathological secretion of one to three enzymes, normal volume and bicarbonate secretion, no steatorrhoea), moderate (II; $\mathrm{n}=14$ ) (pathological secretion of enzymes as well as pathological volume and bicarbonate, no steatorrhoea), and severe (III) exocrine pancreatic insufficiency $(n=22)$ (as II plus steatorrhoea $>7 \mathrm{~g} /$ day). Subclassification was performed according to functional criteria of the secretin-caerulein test only; morphological data were not used for this categorisation.

Faecal elastase concentration and faecal chymotrypsin activity were determined in all 79 patients and furthermore in 50 healthy controls with no pathological clinical and laboratory findings. Table I shows the patients' characteristics of the several groups investigated in detail.
SECRETIN-CAERULEIN TEST

After an overnight fast patients were intubated in the morning at 8 am with a gastroduodenal tube, which was placed up to the ligament of Treitz. After 15 minutes' collection of basal secreted duodenal juice, $1 \mathrm{U}$ secretin $/ \mathrm{kg}$ bwt $/ \mathrm{h}$ was continuously given intravenously for two hours and $30 \mathrm{ng}$ caerulein $/ \mathrm{kg} \mathrm{bwt} / \mathrm{h}$ was simultaneously given intravenously during the second hour. Pancreatic juice was collected in 15 minute aliquots, and volume, $\mathrm{pH}$, bicarbonate, amylase, trypsin, lipase, and elastase were measured by commercial test kits (amylase, lipase, trypsin, from Boehringer/ Mannheim, Germany). The lower normal limits are two SD below the mean values: volume $<150 \mathrm{ml} /$ first hour, bicarbonate $<10$ $\mathrm{mmol} /$ first hour, amylase $<15 \times 10^{3} \mathrm{U} /$ second hour, lipase $<90 \times 10^{3} \mathrm{U} /$ second hour, trypsin $<6 \times 10^{3} \mathrm{U} /$ second hour, and elastase $<16 \times 10^{3}$ $\mu \mathrm{g} /$ second hour.

\section{FAECAL ELASTASE}

Faecal elastase was measured using two monoclonal antibodies specific for human pancreatic elastase 1, which bind to two distinct epitopes of this enzyme ${ }^{1011}$ (test kit from Schebo Tech, 35435 Wettenberg, Germany). The lower detection limit of the elastase 1 assay is below $1 \mathrm{ng} / \mathrm{ml} .{ }^{11}$ The intraassay variance is $5 \cdot 8 \%$, and the interassay variance is $7 \cdot 7 \% .{ }^{11}$ Stool $(100 \mathrm{mg})$ was finally diluted 1:500 and faecal elastase 1 concentration ( $\mu \mathrm{g} / \mathrm{g}$ stool) was calculated photometrically (OD $405 \mathrm{~mm}$ ) in comparison with a standard solution. ${ }^{1011}$

\section{FAECAL CHYMOTRYPSIN}

Faecal chymotrypsin activity (U/g stool) was calculated by photometric estimation with a test kit from Boehringer Mannheim (Germany). ${ }^{20}$ Values were expressed as $\mathrm{U} / \mathrm{g}$ stool and values $<3 \mathrm{U} / \mathrm{g}$ stool were regarded as pathological.

\section{FAECAL FAT ANALYSIS}

Faecal fat excretion was measured by the established method of van de Kamer et $a l^{21}$ with the patients consuming $90 \mathrm{~g}$ fat per day during the three day sample collection period. Steatorrhoea was defined as faecal fat excretion of more than $7 \mathrm{~g}$ fat per day as a mean of a 72 hour collection period.

TABLE I Characteristics of patients

\begin{tabular}{llllll}
\hline & & \multicolumn{2}{l}{$\begin{array}{l}\text { Chronic pancreatitis with exocrine pancreatic } \\
\text { insufficiency }\end{array}$} & $\begin{array}{l}\text { Other } \\
\text { gastrointestinal } \\
\text { diseases }\end{array}$ \\
\cline { 3 - 6 } & $\begin{array}{l}\text { Healthy } \\
\text { controls }\end{array}$ & $I$ (mild) & $I I$ (moderate) & III (severe) & 35 \\
No of patients & 50 & 8 & 14 & 22 & $5 \cdot 0(2 \cdot 5)$ \\
Age (mean (SEM)) & $27 \cdot 4(0 \cdot 8)$ & $35 \cdot 6(5 \cdot 3)$ & $44 \cdot 6(3 \cdot 5)$ & $47 \cdot 2(1 \cdot 6)$ & $52 \cdot 0)$ \\
Sex (male/female) & $26 / 24$ & $5 / 3$ & $10 / 4$ & $15 / 7$ & $22 / 13$ \\
Body weight (mean (SEM)) (\% BROCA) & $90 \cdot 0(2 \cdot 1)$ & $95 \cdot 9(6 \cdot 9)$ & $88 \cdot 9(3 \cdot 2)$ & $78 \cdot 9(1 \cdot 8)$ & $92 \cdot 5(2 \cdot 4)$ \\
Chronic alcoholism (yes/no) & $0 / 50$ & $4 / 4$ & $10 / 4$ & $16 / 8$ & $0 / 35$ \\
Abdominal pain (yes/no) & $0 / 50$ & $5 / 3$ & $12 / 2$ & $18 / 4$ & $27 / 8$ \\
Steatorrhoea (yes/no) & $0 / 50$ & $0 / 8$ & $0 / 14$ & $22 / 0$ & $7 / 28$ \\
Diabetes mellitus (yes/no) & $0 / 50$ & $2 / 6$ & $7 / 7$ & $11 / 11$ & $0 / 35$ \\
Pancreatic calcification (yes/no) & $0 / 50$ & $4 / 4$ & $10 / 4$ & $20 / 2$ & $0 / 35$ \\
\hline
\end{tabular}


CORRELATION STUDIES

Various correlation studies were performed namely, duodenal elastase concentration versus duodenal volume, bicarbonate, amylase, lipase, and trypsin as found in the secretincaerulein test; faecal elastase concentration versus duodenal volume, bicarbonate, amylase, lipase, trypsin, and elastase; faecal elastase versus faecal chymotrypsin; and faecal elastase versus faecal fat excretion. For comparison the same correlations were calculated for faecal chymotrypsin.

DAY TO DAY VARIATIONS

Day to day variations for faecal elastase concentrations and faecal chymotrypsin activities were calculated by daily stool analysis on 10 consecutive days in eight patients. Individual and mean coefficients of variance were determined.

\section{TEMPERATURE DEPENDENCY}

To calculate the temperature dependency of faecal elastase and chymotrypsin analysis over a storage period of one week, the homogenised stool samples of 11 persons were taken, stored at room temperature $\left(+22^{\circ} \mathrm{C}\right),+4^{\circ} \mathrm{C}$ or $-25^{\circ} \mathrm{C}$ for one week. Differences between temperatures were calculated and the results expressed as percentage variation.

\section{STATISTICAL ANALYSIS}

The between group statistical differences were calculated with the Mann-Whitney $U$ test, and regression analysis was performed with the Spearman rank test. ${ }^{22}$ Sensitivity and specificity of faecal elastase and faecal chymotrypsin were compared with the results of the secretin-caerulein test. Values are expressed as mean (SEM).

\section{Results}

Figure 1 depicts individual results of faecal elastase concentration $(\mu \mathrm{g} / \mathrm{g})$ and faecal chymotrypsin activity (U/g). Faecal elastase concentrations $(\mu \mathrm{g} / \mathrm{g})$ in patients with chronic pancreatitis were significantly lower (I: $208 \cdot 3$ (88.2) (p<0.01); II: 28.0 (8.2) (p<0.001); III: $12.5(5.6)(\mathrm{p}<0.001))$ compared with healthy controls $(601.9(38.2))$ or patients with nonpancreatic gastrointestinal diseases (545.9 $(61 \cdot 8))$. By contrast faecal chymotrypsin activity $(\mathrm{U} / \mathrm{g})$ was not significantly reduced in patients with mild pancreatic insufficiency $(9 \cdot 3$ $(3.6) ; \mathrm{p}<0.08)$ compared with healthy controls $(15 \cdot 1(1 \cdot 2))$ and patients with other gastrointestinal diseases $(10 \cdot 2(1 \cdot 3))$. Although patients with moderate $(5 \cdot 2(1.2) ; \mathrm{p}<0.001)$ and severe $(1.7(0.6) ; \mathrm{p}<0.001)$ exocrine pancreatic insufficiency had significantly lower faecal chymotrypsin activities, several patients were above the cut off value of $3 \mathrm{U} / \mathrm{g}$, which was not the situation for faecal elastase concentration in these groups (Fig 1).

Table II shows the sensitivity and specificity of faecal elastase concentrations with a cut off
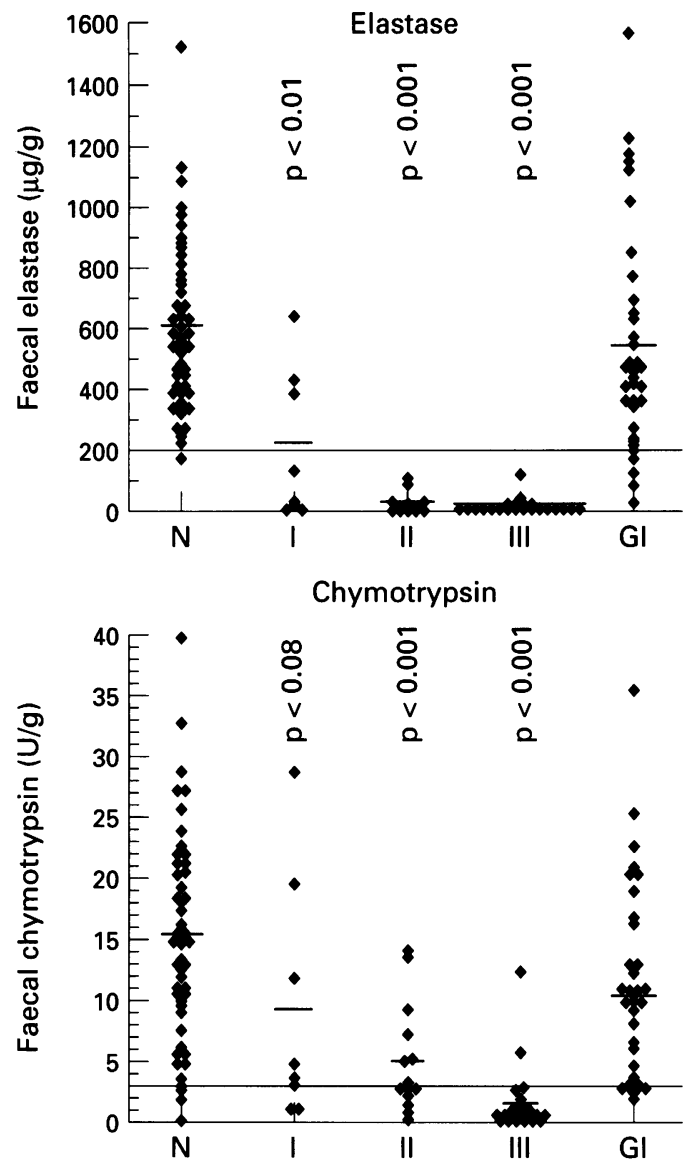

Figure 1: Faecal elastase concentration ( $\mu g / g$ stool) (upper panel) and faecal chymotrypsin activity (U/g stool) (lower panel) in normal healthy controls $(N)$, patients with mild (I), moderate (II), and severe (III) exocrine pancreatic insufficiency according to the secretin-caerulein test, and patients with other gastrointestinal diseases (GI) of nonpancreatic origin. Significance $v N$.

of $100 \mu \mathrm{g} / \mathrm{g}$ stool and $200 \mu \mathrm{g} / \mathrm{g}$ stool and faecal chymotrypsin activity with a cut off of $3 \mathrm{U} / \mathrm{g}$. Faecal elastase concentrations below $200 \mu \mathrm{g} / \mathrm{g}$ stool show a total of $93 \%$ both for sensitivity and specificity, whereas sensitivity for moderate and severe exocrine pancreatic insufficiency is $100 \%$ and for mild insufficiency $63 \%$. By comparison with mild and moderate insufficiency the sensitivity of faecal chymotrypsin amounted to $25 \%$ and $50 \%$ respectively (Table II).

Linear regression analysis showed significant correlations between duodenal as well as faecal elastase concentrations and duodenal trypsin, lipase, amylase, total volume, and bicarbonate

TABLE II Sensitivity and specificity of faecal elastase concentrations ( $\mu \mathrm{g} / \mathrm{g})$ with a cut off of $<100 \mu \mathrm{g} / \mathrm{g}$ or $<200$ $\mu \mathrm{g} / \mathrm{g}$ stool as well as faecal chymotrypsin activity (U/g) with a cut off of $<3 \mathrm{U} / \mathrm{g}$ stool

\begin{tabular}{|c|c|c|c|}
\hline \multirow{2}{*}{$\begin{array}{l}\text { Exocrine } \\
\text { pancreatic } \\
\text { insufficiency }\end{array}$} & \multicolumn{2}{|l|}{ Elastase cut off } & \multirow{2}{*}{$\begin{array}{l}\text { Chymotrypsin } \\
\text { cut off } \\
<3 \text { U/g (\%) }\end{array}$} \\
\hline & $<100 \mu g / g(\%)$ & $<200 \mu g / g(\%)$ & \\
\hline \multicolumn{4}{|c|}{ Sensitivity } \\
\hline I & 50 & 63 & 25 \\
\hline II & 93 & 100 & 50 \\
\hline III & 96 & 100 & 86 \\
\hline \multirow[t]{2}{*}{ total } & 86 & 93 & 64 \\
\hline & 98 & $\begin{array}{c}\text { cificity } \\
93\end{array}$ & 89 \\
\hline
\end{tabular}

I=mild; II=moderate; III=severe; total=total exocrine pancreatic insufficiency as estimated by the secretin-caerulein pancrea 
according to the results of the secretincaerulein test (Figs 2 and 3). Similar analyses showed much lower correlations for faecal chymotrypsin with duodenal trypsin $(0.626$; $\mathrm{p}<0.001)$, lipase $(0.605 ; \mathrm{p}<0.001)$, amylase $(0.635 ; \mathrm{p}<0.001)$, volume $(0.392 ; \mathrm{p}<0.001)$, and bicarbonate $(0.590 ; \mathrm{p}<0.001)$. Furthermore, significant correlations were found for faecal elastase/faecal chymotrypsin (0.724; $\mathrm{p}<0.001)$ and faecal elastase/duodenal elastase $(0.773 ; p<0.001)$, but there was no significant correlation between faecal elastase and faecal fat excretion $(r=-0.336)$.

Repeated daily measurements of elastase concentrations in eight persons on 10 consecutive days showed coefficients of variance between $9 \%$ and $21 \%$ with a mean value of $15 \%$ (Table III). By comparison the coefficients of variance for faecal chymotrypsin ranged between $11 \%$ and $46 \%$ with a mean value of $30 \%$ (Table III).

After one week's storage at different temperatures the faecal elastase concentrations of stool samples from 11 persons varied by mean $6.64 \%$ between $-25^{\circ} \mathrm{C}$ and room temperature, $4 \cdot 13 \%$ between $-25^{\circ} \mathrm{C}$ and $+4^{\circ} \mathrm{C}$, and $2.51 \%$ between $+4^{\circ} \mathrm{C}$ and room temperature. The results for faecal chymotrypsin were
$27 \cdot 52 \%, 10 \cdot 37 \%$, and $17 \cdot 15 \%$ after storage of the stool samples for one week.

\section{Discussion}

Elastase 1 is a proteolytic pancreas specific enzyme with a molecular weight of about 28 $\mathrm{kDa}$ with a special affinity to the carboxyl group of alanine, valine and leucine. ${ }^{10}{ }^{13}$ It was first described in 1975 by Mallory and Travis ${ }^{23}$ as protease $\mathrm{F}$, and further characterised as an elastolytic pancreatic enzyme by Largmann et $a l .{ }^{24}$ Under physiological conditions elastase 1 concentration in pancreatic juice is between 170 and $360 \mu \mathrm{g} / \mathrm{ml}$, which is about $6 \%$ of all secreted pancreatic enzymes. ${ }^{25}$ During intestinal passage elastase 1 is mainly bound to bile salts and it was shown that elastase 1 - by contrast with other pancreatic enzymes - is not degraded during passage through the gut, whereas it is concentrated about five to sixfold in human faeces compared with pancreatic juice. ${ }^{101225}$

Recently published studies comparing faecal elastase 1 concentration with the fluorescein dilaurate test and faecal chymotrypsin activity in patients with chronic pancreatitis disclosed a comparable sensitivity of faecal elastase 1
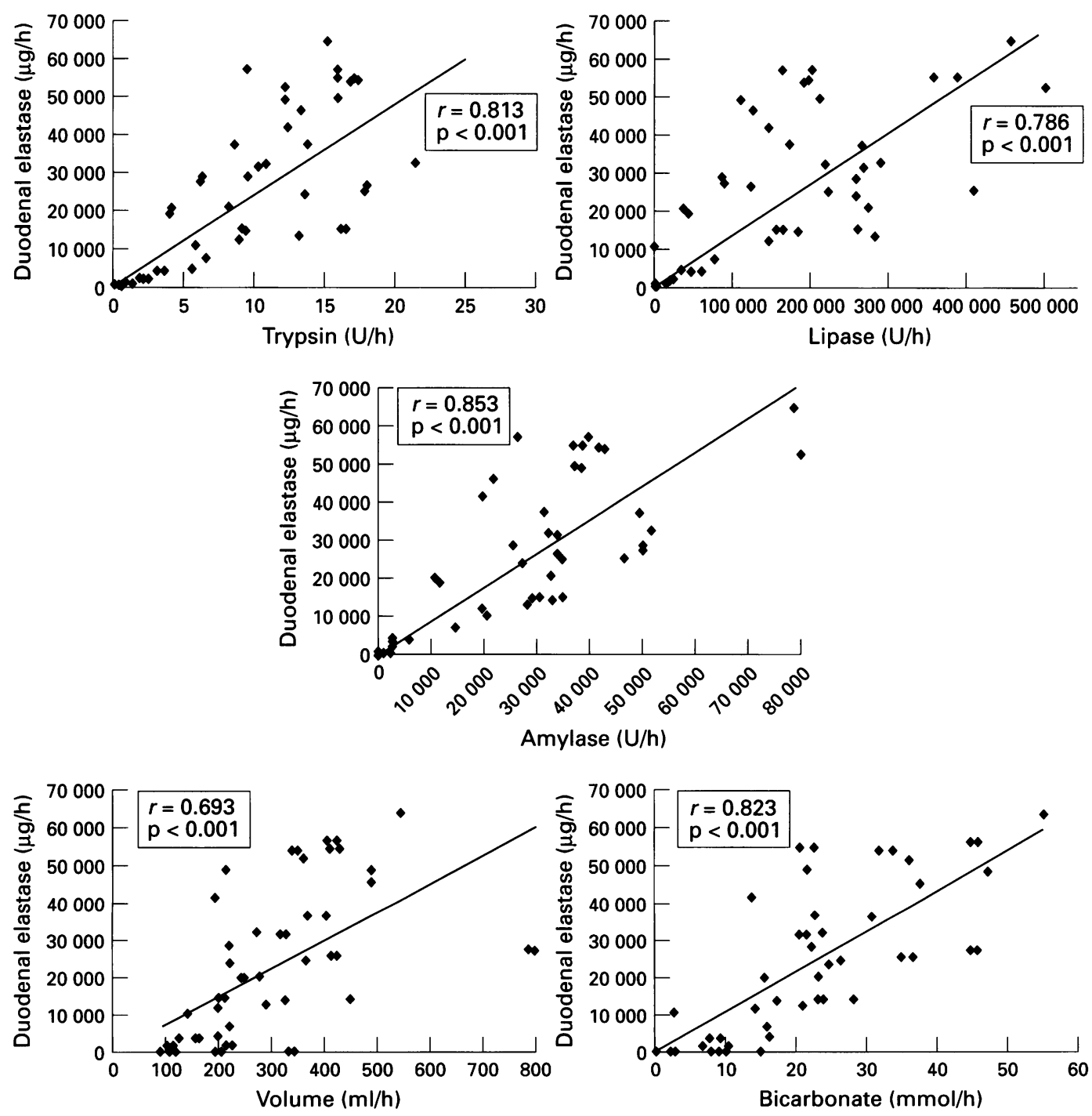

Figure 2: Regression analyses between duodenal elastase and duodenal trypsin, lipase, amylase, volume, and bicarbonate according to the secretin-caerulein test. 

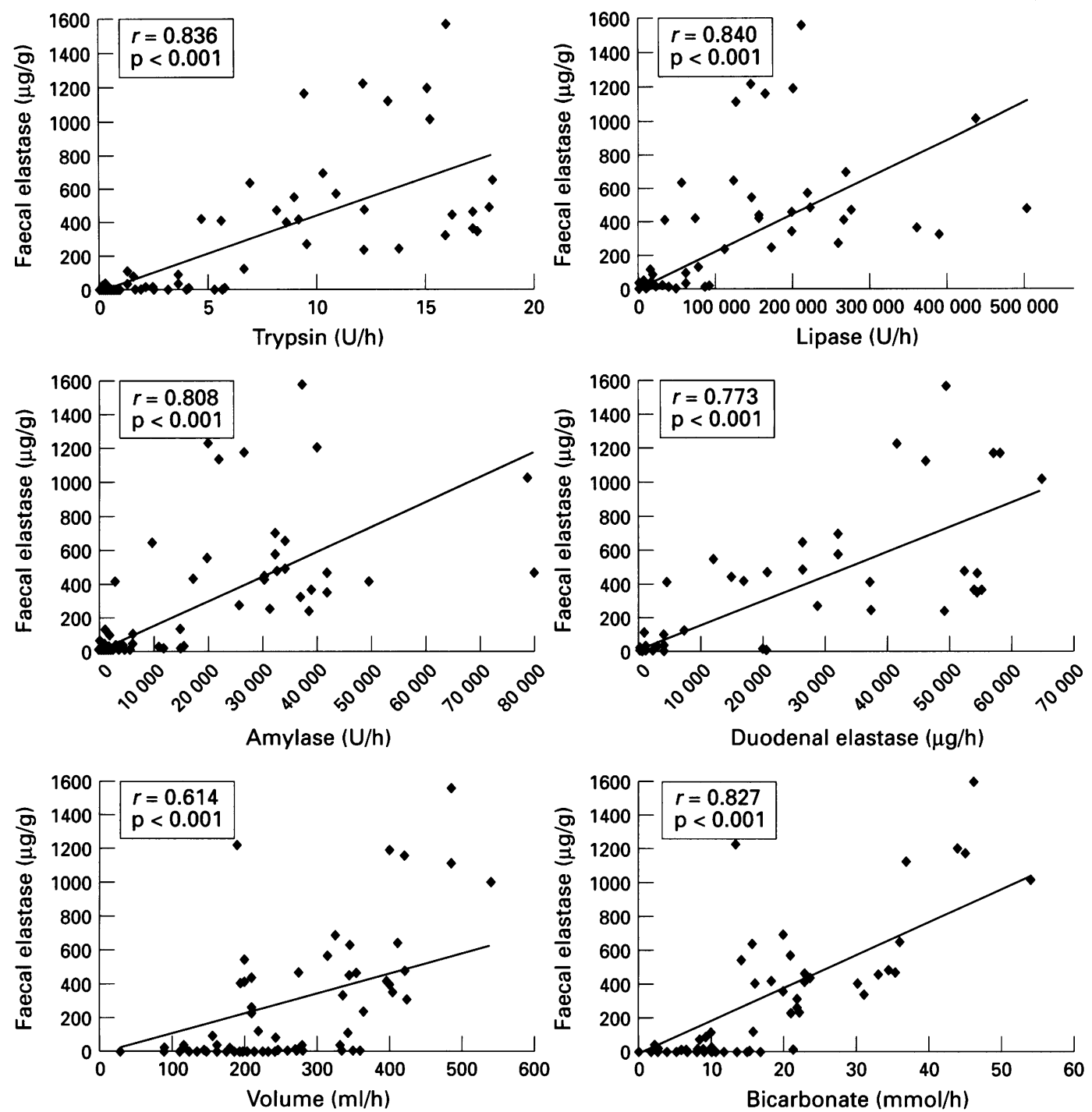

Figure 3: Regression analyses between faecal elastase and duodenal trypsin, lipase, amylase, duodenal elastase, volume, and bicarbonate according to the secretin-caerulein test.

with the fluorescein dilaurate test, whereas determination of faecal chymotrypsin activity was less sensitive. ${ }^{13}{ }^{14}$ In all 11 patients with exocrine pancreatic insufficiency confirmed by the secretin-cholecystokinin test, Stein et al ${ }^{15}$ found faecal elastase 1 concentrations $<150$ $\mu \mathrm{g} / \mathrm{g}$ stool, whereas 21 patients without exocrine pancreatic insufficiency had concentrations above $250 \mu \mathrm{g} / \mathrm{g}$. Katschinski et al $^{16}$ reported a sensitivity and specificity of faecal elastase 1 determination (cut off $<400 \mu \mathrm{g} / \mathrm{g}$ ) for pancreatic insufficiency of $91 \%$ in 23 patients with 11 patients having exocrine pancreatic insufficiency as assessed by a direct tube test. In 204 children with cystic fibrosis Terbrack et $a l^{26}$ found a sensitivity of $89.5 \%$ and a specificity of $99 \%$ for faecal elastase 1 concentration with a cut off of $<200 \mu \mathrm{g} / \mathrm{g}$ stool. These data were confirmed by other investigators, who found faecal elastase 1 concentrations below $15 \mu \mathrm{g} / \mathrm{g}$ in all patients studied with confirmed cystic fibrosis. ${ }^{15}$

Our data confirm those already published indicating that faecal elastase 1 determination is a sensitive and specific test for the detection of decreased exocrine pancreatic function. Furthermore, the present study is the first to present data on the basis of a large cohort of patients with various well defined degrees of exocrine pancreatic insufficiency as measured by the secretin-caerulein test as the 'gold standard' of pancreatic function testing. Our data extend the suggestions of previous investigators by showing $(a)$ that faecal elastase 1 determination with a cut off $<200 \mu \mathrm{g} / \mathrm{g}$ is highly sensitive (93\%) and specific $(93 \%)$ for the detection of exocrine pancreatic insufficiency; (b) subclassification according to the results of the secretin-caerulein test and faecal fat excretion show excellent sensitivity for moderate $(100 \%)$ and severe $(100 \%)$ and sufficient but limited sensitivity for mild (63\%) exocrine pancreatic insufficiency; $(c)$ overall sensitivity of faecal elastase $1(93 \%)$ is much higher than that of faecal chymotrypsin $(64 \%)$; $(d)$ elastase 1 shows a very similar excretion pattern to the other pancreatic enzymes and faecal elastase 1 concentration is highly significantly correlated with duodenal enzyme and volume output; (e) faecal elastase 1 analysis proved to be of high clinical practicability with low individual day to day variability and excellent stability under various storage conditions.

Faecal elastase 1 concentrations $<100 \mu \mathrm{g} / \mathrm{g}$ are found in mild and moderate as well as 
TABLE III Day to day variations of faecal elastase concentrations $(\mu \mathrm{g} / \mathrm{g})$ and faecal chymotrypsin activity (U/g) in eight persons $(P)$ on 10 consecutive days

\begin{tabular}{|c|c|c|c|c|c|c|c|c|}
\hline Day & $P 1$ & $P 2$ & P3 & P4 & P5 & P6 & P7 & P8 \\
\hline $\begin{array}{r}1 \\
2 \\
3 \\
4 \\
5 \\
6 \\
7 \\
8 \\
9 \\
10\end{array}$ & $\begin{array}{l}611 \cdot 9 \\
490 \cdot 1 \\
575 \cdot 4 \\
464 \cdot 3 \\
424 \cdot 4 \\
471 \cdot 0 \\
517 \cdot 1 \\
486 \cdot 0 \\
417 \cdot 5 \\
478 \cdot 5\end{array}$ & $\begin{array}{l}333 \cdot 5 \\
303 \cdot 2 \\
345 \cdot 0 \\
354 \cdot 7 \\
278 \cdot 0 \\
217 \cdot 2 \\
218 \cdot 1 \\
234 \cdot 1 \\
286 \cdot 3 \\
352 \cdot 6\end{array}$ & $\begin{array}{c}F a e \\
458 \cdot 5 \\
302 \cdot 8 \\
411 \cdot 6 \\
330 \cdot 3 \\
363 \cdot 2 \\
361 \cdot 6 \\
335 \cdot 5 \\
366 \cdot 3 \\
419 \cdot 4 \\
433 \cdot 4\end{array}$ & $\begin{array}{c}\text { elastase } \\
523 \cdot 4 \\
517 \cdot 2 \\
478 \cdot 6 \\
426 \cdot 2 \\
413 \cdot 1 \\
351 \cdot 2 \\
402 \cdot 2 \\
331 \cdot 8 \\
317 \cdot 8 \\
425 \cdot 0\end{array}$ & $\begin{array}{l}g / g) \\
696 \cdot 0 \\
511 \cdot 8 \\
560 \cdot 7 \\
549 \cdot 7 \\
594 \cdot 6 \\
595 \cdot 6 \\
597 \cdot 4 \\
567 \cdot 5 \\
588 \cdot 5 \\
519 \cdot 1\end{array}$ & $\begin{array}{l}825 \cdot 7 \\
596 \cdot 3 \\
611 \cdot 5 \\
517 \cdot 2 \\
613 \cdot 3 \\
690 \cdot 1 \\
654 \cdot 5 \\
687 \cdot 0 \\
772 \cdot 6 \\
792 \cdot 1\end{array}$ & $\begin{array}{l}390 \cdot 7 \\
244 \cdot 0 \\
356 \cdot 5 \\
220 \cdot 5 \\
226 \cdot 3 \\
355 \cdot 4 \\
364 \cdot 1 \\
348 \cdot 5 \\
292 \cdot 0 \\
257 \cdot 9\end{array}$ & $\begin{array}{l}408 \cdot 3 \\
507 \cdot 6 \\
464 \cdot 4 \\
487 \cdot 9 \\
611 \cdot 7 \\
678 \cdot 7 \\
575 \cdot 0 \\
637 \cdot 7 \\
647 \cdot 7 \\
617 \cdot 6\end{array}$ \\
\hline $\begin{array}{l}\text { Mean } \\
\text { SD } \\
\text { median }\end{array}$ & $\begin{array}{r}493 \cdot 6 \\
61 \cdot 0 \\
482 \cdot 2\end{array}$ & $\begin{array}{r}292.3 \\
54 \cdot 7 \\
294.8\end{array}$ & $\begin{array}{r}378 \cdot 2 \\
50 \cdot 3 \\
364 \cdot 7\end{array}$ & $\begin{array}{r}418 \cdot 6 \\
72 \cdot 2 \\
419 \cdot 1\end{array}$ & $\begin{array}{r}578 \cdot 1 \\
51 \cdot 7 \\
578 \cdot 0\end{array}$ & $\begin{array}{r}676.0 \\
97.5 \\
670 \cdot 7\end{array}$ & $\begin{array}{r}305 \cdot 6 \\
64 \cdot 4 \\
320 \cdot 3\end{array}$ & $\begin{array}{r}563.6 \\
90.7 \\
593.3\end{array}$ \\
\hline $\mathrm{CV}(\%)$ & $12 \%$ & $19 \%$ & $13 \%$ & $17 \%$ & $9 \%$ & $14 \%$ & $21 \%$ & $16 \%$ \\
\hline $\begin{array}{r}1 \\
2 \\
3 \\
4 \\
5 \\
6 \\
7 \\
8 \\
9 \\
10\end{array}$ & $\begin{array}{l}13 \cdot 9 \\
15 \cdot 2 \\
16 \cdot 7 \\
11 \cdot 0 \\
13 \cdot 9 \\
14 \cdot 6 \\
16 \cdot 3 \\
14 \cdot 4 \\
13 \cdot 6 \\
15 \cdot 5\end{array}$ & $\begin{array}{r}13.4 \\
8.9 \\
17.7 \\
12.2 \\
7.8 \\
9.7 \\
6.6 \\
9.5 \\
5.6 \\
22.5\end{array}$ & $\begin{array}{r}\text { Faecal } \\
7 \cdot 9 \\
8 \cdot 5 \\
11 \cdot 2 \\
6 \cdot 7 \\
5 \cdot 8 \\
7 \cdot 9 \\
11.5 \\
10 \cdot 6 \\
16 \cdot 0 \\
11 \cdot 1\end{array}$ & $\begin{array}{r}y m o t r y p \\
21.5 \\
15.1 \\
9.9 \\
7.0 \\
17.5 \\
2.6 \\
16.0 \\
15.8 \\
17.0 \\
18.1\end{array}$ & $\begin{array}{c}(U / g) \\
20 \cdot 2 \\
15 \cdot 8 \\
16 \cdot 4 \\
17 \cdot 6 \\
15 \cdot 5 \\
19 \cdot 5 \\
15 \cdot 0 \\
21 \cdot 9 \\
16 \cdot 6 \\
13 \cdot 4\end{array}$ & $\begin{array}{l}21 \cdot 7 \\
21.9 \\
18.5 \\
16.4 \\
13.6 \\
15 \cdot 6 \\
22 \cdot 1 \\
26 \cdot 8 \\
23.6 \\
25.5\end{array}$ & $\begin{array}{r}7 \cdot 1 \\
5 \cdot 4 \\
4 \cdot 6 \\
3 \cdot 3 \\
6 \cdot 1 \\
7 \cdot 5 \\
7 \cdot 4 \\
13 \cdot 9 \\
9 \cdot 9 \\
13 \cdot 3\end{array}$ & $\begin{array}{l}4 \cdot 8 \\
5 \cdot 5 \\
3 \cdot 1 \\
5 \cdot 1 \\
7 \cdot 6 \\
9 \cdot 1 \\
5 \cdot 7 \\
5 \cdot 4 \\
6 \cdot 3 \\
5 \cdot 2\end{array}$ \\
\hline $\begin{array}{l}\text { Mean } \\
\text { SD } \\
\text { median }\end{array}$ & $\begin{array}{r}14.5 \\
1.6 \\
14.5\end{array}$ & $\begin{array}{r}11 \cdot 4 \\
5.3 \\
9.6\end{array}$ & $\begin{array}{l}9 \cdot 7 \\
3.0 \\
9.5\end{array}$ & $\begin{array}{r}14.0 \\
5.8 \\
15.9\end{array}$ & $\begin{array}{r}17 \cdot 2 \\
2 \cdot 6 \\
16 \cdot 5\end{array}$ & $\begin{array}{r}20 \cdot 5 \\
4 \cdot 4 \\
21 \cdot 8\end{array}$ & $\begin{array}{l}7 \cdot 8 \\
3 \cdot 5 \\
7 \cdot 2\end{array}$ & $\begin{array}{l}5 \cdot 8 \\
1.6 \\
5 \cdot 5\end{array}$ \\
\hline $\mathrm{CV}$ & $11 \%$ & $46 \%$ & $31 \%$ & $41 \%$ & $15 \%$ & $21 \%$ & $45 \%$ & $28 \%$ \\
\hline
\end{tabular}

$\mathrm{CV}=$ Coefficient of variance (mean for faecal elastase $15 \%$; mean for faecal chymotrypsin $30 \%$ ).

severe exocrine pancreatic insufficiency and are therefore not characteristic for severe cases only. On the other hand, the sensitivity in mild cases is limited, with a cut off $<200 \mu \mathrm{g} / \mathrm{g}$ as three out of eight patients had elastase 1 concentrations above that concentration. Nevertheless, a sensitivity of $63 \%$ in these mild cases is much higher compared with other indirect pancreatic function tests available, and a sensitivity of $100 \%$ even in moderate exocrine pancreatic insufficiency is not reported for any other tubeless test either. ${ }^{1358}$ In a well documented meta-analysis, overall sensitivity for mild and moderate chronic pancreatitis assessed by the secretin-caerulein test was $39 \%$ for the fluorescein dilaurate test, $46 \%$ for the NBT-PABA test, and $49 \%$ for faecal chymotrypsin determination, whereas sensitivities for severe cases were $79 \%, 71 \%$ and $85 \%$ respectively. ${ }^{1}$

The presented results differ from data by Amann $e t a l^{27}$ who found normal $(>200 \mu \mathrm{g} / \mathrm{g})$ faecal elastase 1 concentrations in four out of seven patients with mild to moderate exocrine pancreatic insufficiency. This low sensitivity might be due to the different subclassification criteria in this study: whereas Amann et $a l^{27}$ subclassified their 13 patients according to a combined parameter score with morphological (calcifications, ERP, surgery) and functional (secretin test) criteria, subclassification in the present study was performed according to functional criteria ${ }^{3}{ }^{19}$ only, although morphological criteria ${ }^{17}{ }^{18}$ had to be present to confirm the diagnosis. Evaluation of a novel function test should be based on the best established functional variable as subclassification standard, which is the secretin-caerulein test.

Significant correlations between faecal as well as duodenal elastase 1 concentrations and duodenal lipase, amylase, trypsin, volume, and bicarbonate were found, which proves that secretion patterns of elastase are similar to those of other pancreatic enzymes. Furthermore, faecal elastase 1 was highly significantly correlated to duodenal elastase 1 concentrations, which clearly confirms the suggestions of other investigators that measurement of faecal elastase 1 is representative of pancreatic elastase 1 secretion. ${ }^{10} 25$

This study disclosed very low individual day to day variations of faecal elastase 1 concentrations, confirming results of studies in children with cystic fibrosis. ${ }^{26}$ Faecal elastase 1 determination does not require analysis of different stool samples as a single analysis of a normal $100 \mathrm{mg}$ stool sample proved to be sufficient and should only be repeated in uncertain cases with faecal elastase 1 concentrations in the borderline area around $200 \mu \mathrm{g} / \mathrm{g}$ stool. Furthermore, faecal elastase 1 was found to be stable over a storage period of one week, even at room temperature, as also described by other investigators ${ }^{28}$ and this makes handling and even mailing of a small stool sample straightforward and easy. As monoclonal antibodies against human pancreatic elastase are used in the ELISA kit, ${ }^{10} 11$ faecal elastase 1 determination is not affected by simultaneous enzyme replacement therapy with pancreatin of animal origin. ${ }^{28}$

In conclusion, the data of the present study show the excellent sensitivity of faecal elastase 1 determination for moderate and severe exocrine pancreatic insufficiency and its limited sensitivity for mild disease. At present faecal elastase 1 determination is the most sensitive and specific tubeless pancreatic function test available, and furthermore proved to be a rapid and easy to handle routine method.

Parts of the study were published in abstract form at the European Pancreatic Club Meeting in Barcelona, Spain (Digestion 1995; 56: 301) and at the IVth United European Gastroenterology Week in Berlin/Germany (Gut 1995; 37: A140).

1 Niederau C, Grendell JH. Diagnosis of chronic pancreatitis. Gastroenterology 1985; 88: 1973-95.

2 Steer ML, Waxman I, Freedman S. Chronic pancreatitis. $N$ Engl f Med 1995; 332: 1482-90.

3 Lankisch PG. Function tests in the diagnosis of chronic pancreatitis. Int $\mathcal{f}$ Pancreatol 1993; 14: 9-20.

4 Go VLW, DiMagno EP. Assessment of exocrine pancreatic function by duodenal intubation. Clin Gastroenterol 1984; 13: 701-5.

$5 \mathrm{Li} \mathrm{Y,} \mathrm{Chiverton} \mathrm{SG,} \mathrm{Hunt} \mathrm{RH.} \mathrm{Exocrine} \mathrm{pancreatic}$ function tests: a review. Can 7 Gastroenterol 1989; 3: 153-61.

6 Löser Chr, Fölsch UR. Diagnostik der chronischen Pankreatitis. Dtsch Med Wochenschr 1996; 121: 243-7.

7 DiMagno EP. Diagnosis of chronic pancreatitis: are noninvasive tests of exocrine pancreatic function sensitive and specific? Gastroenterology 1982; 83: 143-6.

8 Bank S, Chow KW. Diagnostic tests in chronic pancreatitis. Gastroenterologist 1994; 2: 224-32.

9 Ammann RW, Bühler H, Pei P. Comparative diagnostic accuracy of four tube-less pancreatic function tests in chronic pancreatitis. Scand $\mathcal{F}$ Gastroenterol 1982; 17: 997-1002.

10 Sziegoleit A, Krause E, Klör HU, Kranacher L, Linder D. Elastase 1 and chymotrypsin $B$ in pancreatic juice and feces. Clin Biochem 1989; 22: 85-9.

11 Scheefers-Borchel U, Scheefers H, Arnold R, Fischer P, Sziegoleit A. Pankreatische Elastase 1: Parameter für die Sziegoleit A. Pankreatische Elastase 1: Parameter für die 427-32.

12 Sziegoleit A, Linder D. Studies on the sterol-binding capacity of human pancreatic elastase. Gastroenterology 1991; 100: 768-74.

13 Dominguez-Munoz JE, Hieronymus C, Sauerbruch T, Malfertheiner P. Fecal elastase test: Evaluation of a new 
noninvasive pancreatic function test. Am $\mathcal{F}$ Gastroenterol 1995; 90: 1834-7.

14 Glasbrenner B, Beckh KH, Adler G. Comparison of fecal elastase 1 with other indirect pancreatic function tests [abstract]. Digestion 1994; 55: 301-2.

15 Stein J, Jung M, Bienek U, Scheefers $H$, Lembcke $B$, Caspary WF. Fäkale Pankreas-Elastase 1 (E1). Ein neuer zuverlässiger Parameter zur Diagnose der exokrinen Pankreasinsuffizienz [abstract]. Z Gastroenterol 1993; 31: 543.

16 Katschinski M, Schirra J, Bross A, Arnold R, Göke B. Fecal concentration of pancreatic elastase 1 accurately indicates exocrine pancreatic insufficiency [abstract]. Gastroenterology 1994; 106: A-79.

17 Axon ATR, Classen M, Cotton PB, Cremer M, Freeny PC, Lees WR. Pancreatography in chronic pancreatitis: international definitions. Gut 1984; 25: 1107-12.

18 Sarner M, Cotton PB. Classification of pancreatitis. Gut 1984; 25: 756-9.

19 Lankisch PG, Schreiber A, Otto J. Pancreolauryl-test. Evaluation of a tubeless pancreatic function test in Evaluation of a tubeless pancreatic function test in
comparison with other indirect and direct tests for exocrine pancreatic function. Dig Dis Sci 1983; 28: exocrine

20 Kaspar P, Möller G, Wahlefeld AW, Stachler F. A new photometric method for determination of chymotrypsin in stool. Fresenius Zeitschrift fur Analytische Chemie 1982; 311: 391-2.

21 van de Kamer JH, ten Bokkel Huinink H, Weyers HA Rapid method for the determination of fat in feces. $7 \mathrm{Biol}$ Chem 1949; 177: 347-55.

22 Zar JH. Biostatistical analysis. 2nd ed. Englewood Cliffs, New Jersey: Prentice Hall, 1984

23 Mallory PA, Travis A Human pancreatic enzymes: purification and characterization of a nonelatolytic purification and characterization of

24 Largmann C, Brodrick JW, Geokas MC. Purification and characterization of two human pancreatic elastases. Biochemistry 1976; 15: 2491-500.

25 Sziegoleit A. A novel proteinase from human pancreas. Biochemical f 1984; 219: 735-42.

26 Terbrack HG, Gürtler KH, Klör HU, Lindemann H Human pancreatic elastase 1 concentration in faeces of healthy children and children with cystic fibrosis [abstract]. Gut 1995; 37 (suppl 2): A253.

27 Amann ST, Bishop M, Toskes PP. Fecal pancreatic elastase $1:$ is it the test we have been looking for? [abstract] 1: is it the test we have been

28 Stein J, Jung M, Sziegoleit A, Zeuzem S, Lembcke B, Caspary WF, Lembcke B. Immunoreactive elastase 1 : clinical evaluation of a new noninvasive test of pancreatic function. Clin Chem 1996; 42: 222-6. 